\title{
Cyclooxygenase Inhibitor
}

National Cancer Institute

\section{Source}

National Cancer Institute. Cyclooxygenase Inhibitor. NCI Thesaurus. Code C1323.

Any agent that inhibits prostaglandin $\mathrm{G} / \mathrm{H}$ synthase (cyclooxygenase or COX), an enzyme

that catalyzes the production of prostanoids, including prostaglandins, prostacyclin and thromboxane, from arachidonic acid. Cyclooxygenase inhibitors are a type of nonsteroidal anti-inflammatory drug. 